\title{
LCP パイプ射出成形品のエネルギー吸収特性
}

尾本 正 明*1 森 直 樹 ${ }^{* 1}$-井上 敏 夫*2

\section{1.はじめに}

近年，金属材料として軽量でありかつ強度的に優れた瀻 維強化プラスチックス（FRP）が金属材料に代わる材料と して様々な分野で注目され用途開発が進んできている. 自 動車産業分野においても搭乗者を衝突時の衝撃から保護す るための衝突安全性部材であるエネルギー吸収部材への適 用が検討されている1). 一方，エネルギー吸収部材の特性 や破壊挙動に関する報告もされている2)-5).

しかしながら，これらに用いられているエネルギー吸収 部材は熱硬化性樹脂と平織ガラスクロスを幾重にも積層さ せた構造体であるため成形加工に手間を要し, コスト高で あるという問題がある.

そこで，本開発では，FRP 製では成形加工に手間を要 し，コスト高であるという問題を解決したエネルギー吸収 部材を熱可塑性樹脂の射出成形に配向を制御する技術を付 加させることで実現させたので報告する.

\section{2. 材料および成形}

熱可塑性樹脂として液晶ポリマー（LCP）を選定し使用 した．これは，LCP の特長である異方性と自己補強特性 を活用するためである. 詳しくは, 日本石油化学(侏より提 供頂いた “Xydar ${ }^{\circledR ”}$ (BP Amoco Polymers, Inc., part of the BP Amoco Group.）を用いた。試作品はパイプ形状とし， 大小 2 種類の成形品を成形した. LCP 大パイプ (L-tube) は外径 $32 \mathrm{~mm}$, 肉厚 $3.5 \mathrm{~mm}$, 配向角を $15^{\circ}$ に制御した成 形品である. LCP 小パイプ (S-tube) は外径 $19 \mathrm{~mm}$, 肉 厚 $1.0 \mathrm{~mm}$ ，配向角を $30^{\circ}$ に制御した成形品である.

成形するにあたり，パイプの中空部を回転配向させる回 転コアを内蔵する金型と配向制御装置を使用した ${ }^{6), 7)}$.

試作品の形状を図 1 に示す。

${ }^{* 1}$ Omoto, Masaaki/Mori, Naoki 侏)メイホー 新規事業推進開発部 R\&D センター 直方市感田 811-1（广822-0001）

*2 Inoue, Toshio 日本石油化学(侏) 知的財産室 東京都千代田区内幸町 1-3-1（テ100-8530） 2001.4.19 受理

\section{3. 圧壊試験}

配向制御した試作品（配向制御品）と配向制御していな い試作品（通常成形品）の L-tube, S-tube それぞれにつ いて静的圧壊試験と動的圧壊試験を実施した.

\section{1 圧壊圧子}

圧壊試験の実施では，圧壊挙動を安定させるための圧壊 圧子（Trigger）を使用した. Trigger を図 2 に示す.

\subsection{L-tube および S-tube の静的圧壊試験}

静的圧壊試験は万能圧縮試験機を用いた。試作品の上面 に, 図 2 にて示したTrigger をセットし, $5 \mathrm{~mm} / \mathrm{min}$ の速 度にて圧壊させた。試験概略図を図 3 に示す。

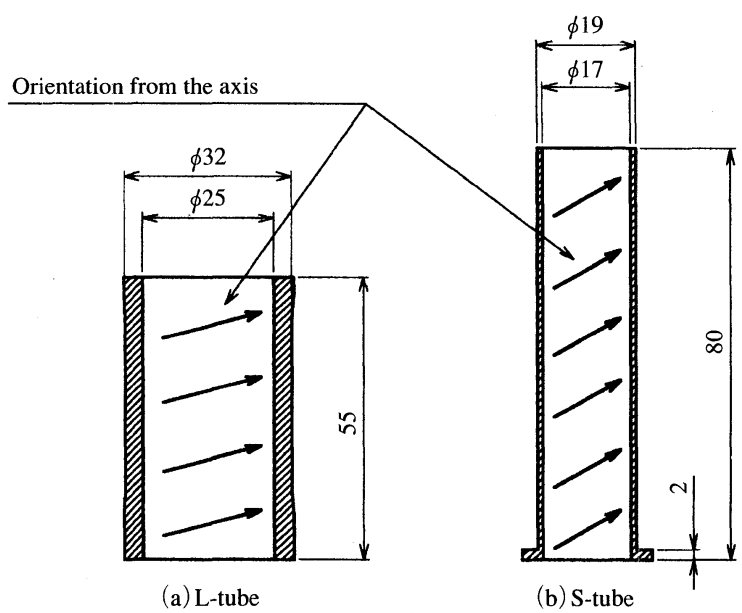

図 1 LCP パイプの配向概要

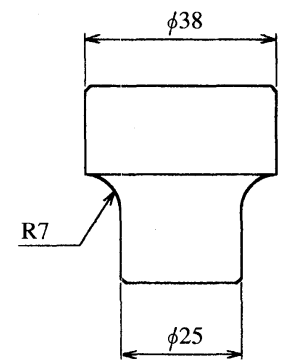

(a)L-tube用

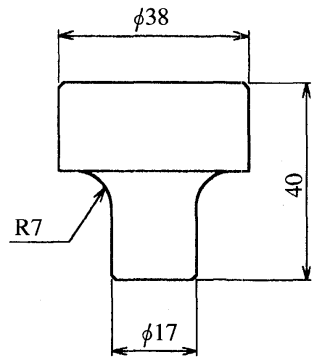

(b) S-tube用
図 2 Trigger $の$ 形状 


\subsection{L-tube の動的圧壊試験}

L-tube の動的圧壊試験は $118.5 \mathrm{~kg}$ の錐体を $2.8 \mathrm{~m} / \mathrm{s}$ の 速度で自由落下させて圧壊させる方法を用いた．L-tube の試験概略図を図 4 に示す。

\subsection{S-tube の動的圧壞試験}

S-tube の動的圧壊試験は独自に製作した試験治具を用 いた. S-tubeの試験概要図を図 5 に示す。

試験は，透明パイプの右片側に Trigger をセットしたStube を㨂入し，圧力調整された皇素ガスにて対面の破壊 壁に向けて衝突させる。飛翔する Trigger と S-tube は破

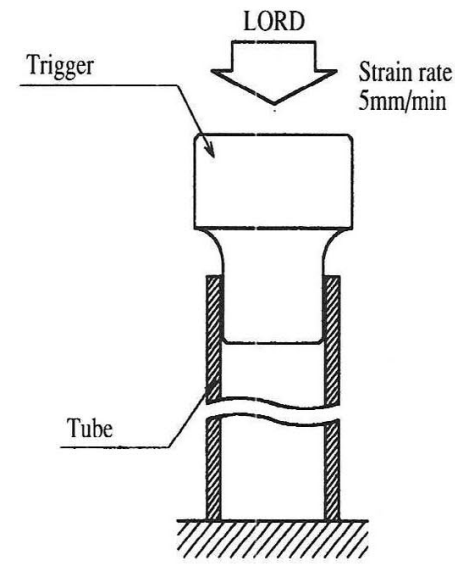

図 3 L-tube および S-tube の静的圧壊試験概要図

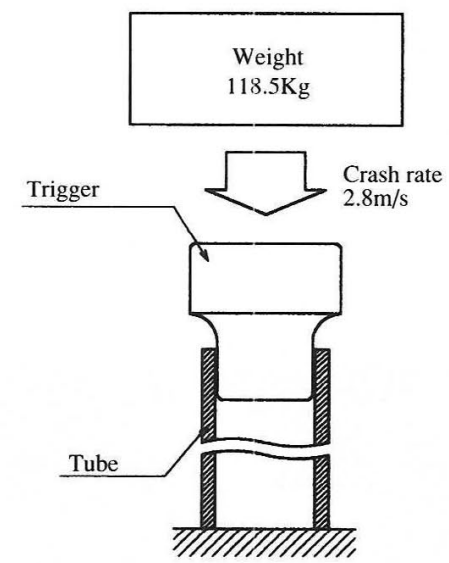

図 4 L-tube の動的圧壊試験概要図

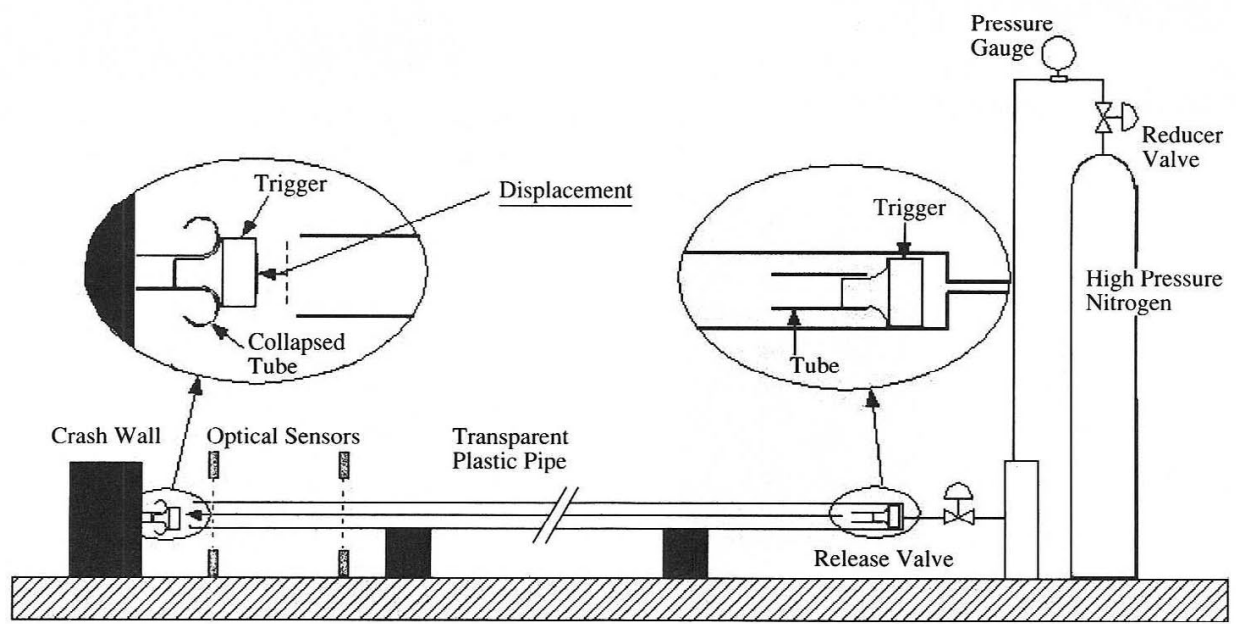

図 5 S-tube の動的圧壊試験治具の概要図
壊壁に激突し， Trigger の運動エネルギーでS-tube を圧 壊する. S-tube が破壊壁に激突し衝撃圧壊する際の速度 を光ファイバセンサーを用いて測定させ，また，破壊壁に 埋め込んでいるロードセルにて応力ー時間特性曲線を計測 した. Triggerの重量 $\left(M_{T}\right)$ と衝撃速度 $\left(R_{C}\right)$ を変化さ せた場合のエネルギー吸収特性を測定し検討を行った。

\section{4. 結果および考察}

\section{1 静的圧壊試験}

L-tube および S-tube の通常成形品は，LCP の射出流動 方向に発生する樹脂の融合部（ウエルドライン）に龟裂が 発生し，竹を割ったような状態にてぜい性的に全体が圧壊 した (図 6(b), 図 8(b))。

一方，L-tube および S-tube の配向制御品は，全圧壊し ないため全長の約半分位の位置で試験を中止した．圧壊状 態は 7 8のクラックにより分割されて花が咲いたように 生じ, 各片では剥離が生じている.また，クラックの表面 と剥離している表面に分裂した瀻維物が見られる（図 7(b), 図 $9(\mathrm{~b}))$.

L-tube 通常成形品の荷重-変位曲線を見ると初期応力上 昇後，急降下している(図6(a))。

一方，配向制御された L-tube の何重一変位曲線を見ると 初期応ノ上昇後， $2.2 \mathrm{kN}$ あたりで平坦な曲線を示してい る(図 $7($ a) )。また，配向制御された S-tube の荷重一変位 曲線も同様に $1.1 \mathrm{kN}$ あたりで細かな振動曲線が平坦に続

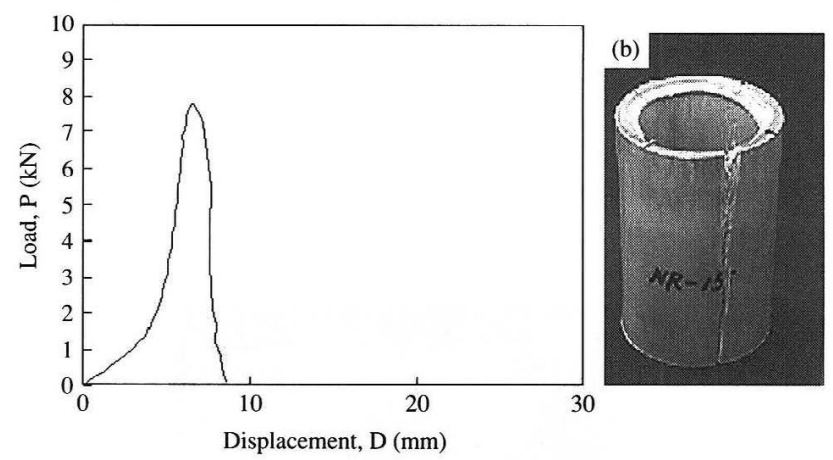

図 6 静的圧壊試験における L-tube 通常成形品のエネル ギー吸収特性 (a) と試験後の状態 (b) 


\section{いている(図 $9(\mathrm{a})$ ).}

このように，通常成形品と配向制御品の強度相違は試作 品外面の配向角と内面の配向角が螺旋状に交差しているこ とに起因していると考える。すなわち，L-tube の場合は 外面が $+15^{\circ}$ に螺旋配向し, 内面は $-15^{\circ}$ に螺旋配向して分 子配列が交差している。同様に，S-tube の場合は外面が $+30^{\circ}$ に蝶旋配向し，内面は $-30^{\circ}$ に螺旋配向して分子配 列が交差している。この螺旋配向の交差が軸方向のクラッ ク伝播の抵抗として作用しエネルギーを吸収しているもの であると考える。配向制御品の配向状態図を図 10 に示す。

配向品の圧壊状態において見られた剥離現象は配向制御 成形の過程において形成された幾層もの薄層状構造による ものであると考える。これらの圧壊様式は，熱硬化性樹脂 にて製作されたエネルギー吸収部材で観察されている “progressive crushing” (連続的な破壊進行) と同等なもの であると考えられる。

\section{2 動的圧壊試験}

L-tube の動的圧壊試験後の状態を図 11 に示す。また, S-tube の動的压壊試験における荷重一時間曲線と Trigger 重量 $\left(M_{T}\right)$ と衝撃速度 $\left(R_{C}\right)$ を変化させた場合の圧壊変 化状態を図 12 に示す。
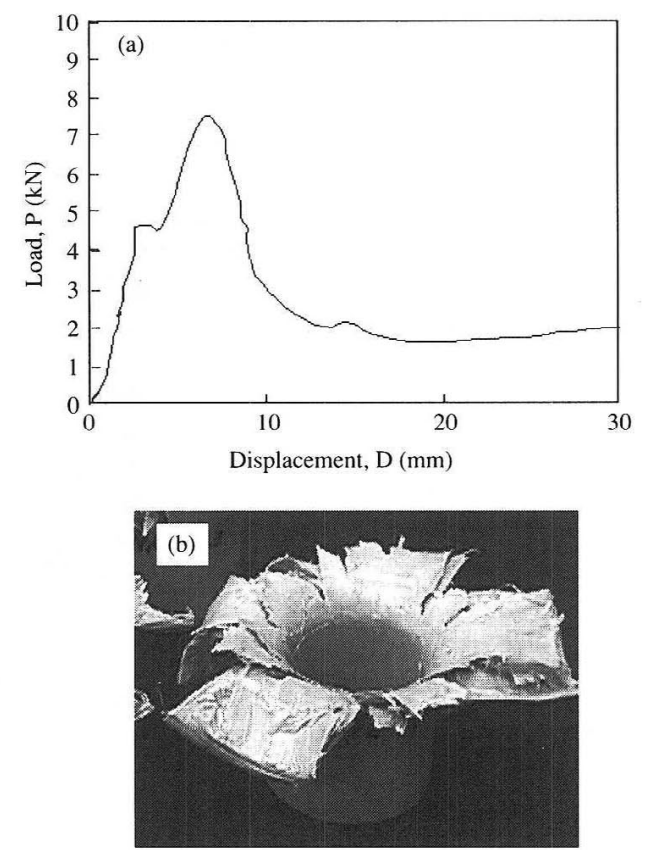

図 7 静的圧壊試験における L-tube 配向制御成形品の エネルギー吸収特性 (a) と試験後の状態 (b)
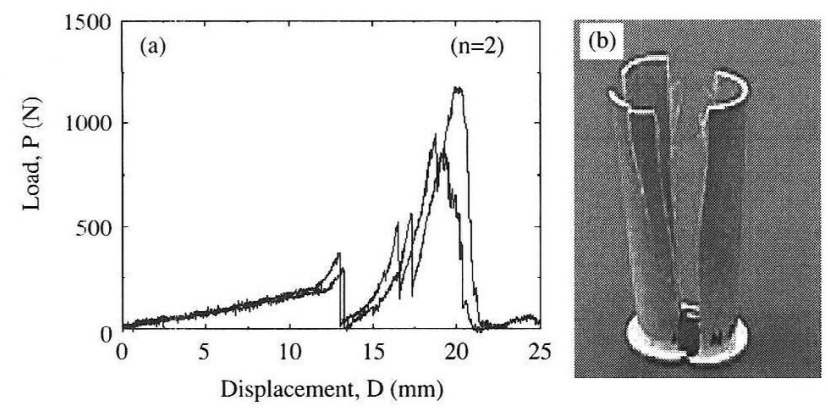

図 8 静的圧壊試験における S-tube 通常成形品のエネル ギー吸収特性 (a) と試験後の状態 (b)
L-tube および S-tube の動的圧壊試験での結果は, 荷重一 変位曲線のピークに多少の相違はあるものの圧壊形態は前 項の静的圧壊試験と同様な結果を示した. L-tube および S tube の静的圧壞試験と動的圧壊試験の圧壊形態を見比べ た場合（図 7(b) と図 11(b) および図 9 (b) と図 $12(\mathrm{~b})$ )，配 向された LCP パイプは類似した圧壞形態を示しているこ とより速度依存性はないと考える。

また, S-tubeの動的庄壞試験より Trigger 重量 $\left(M_{T}\right)$ と衝撃速度 $\left(R_{C}\right)$ を組み合わせた場合, Trigger が衝撃 力により S-tube へ食い达んだ変位 $\left(D_{L}\right)$ と衝撃エネルギー $\left(G_{I}\right)$ についてまとめた。絬果を図 13 に示す。

図 13 内のプロットは $M_{T}(\mathrm{~g}) / R_{C}(\mathrm{~m} / \mathrm{s})$ を示す。例えば, =310/6 は Trigger 重量 $310 \mathrm{~g}$ と衝撃速度 $6 \mathrm{~m} / \mathrm{s}$ の組み 合せによる試験結果である。ここで衝撃エネルギー $\left(G_{I}\right.$ : $\mathrm{kJ})$ は次式より算出した。また， $D_{I}(\mathrm{~mm})$ は実測值である.

$$
\text { 衝撃エネルギー }\left(G_{I}\right)=\frac{M_{T} X\left(R_{C}\right)^{2}}{2}
$$

S-tube が衝撃圧壊する際の熱変換エネルギーと弾性要素 を無視するならば, Trigger 変位 $D_{L}$ は単位圧壊長さあた
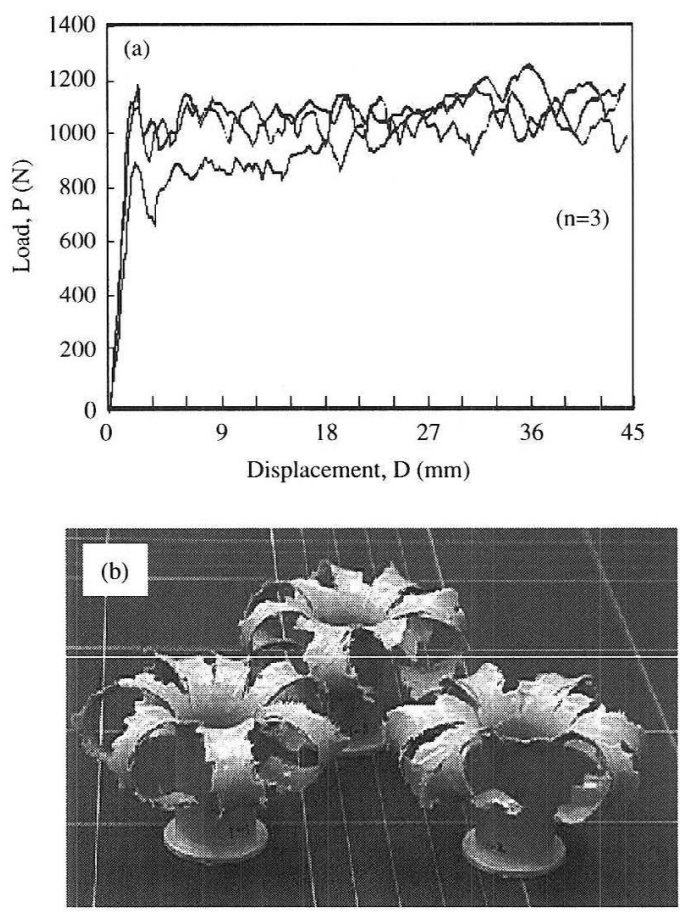

図 9 静的圧壊試験における S-tube 配向制御成形品の エネルギー吸収特性 (a) と試験後の状態 (b)

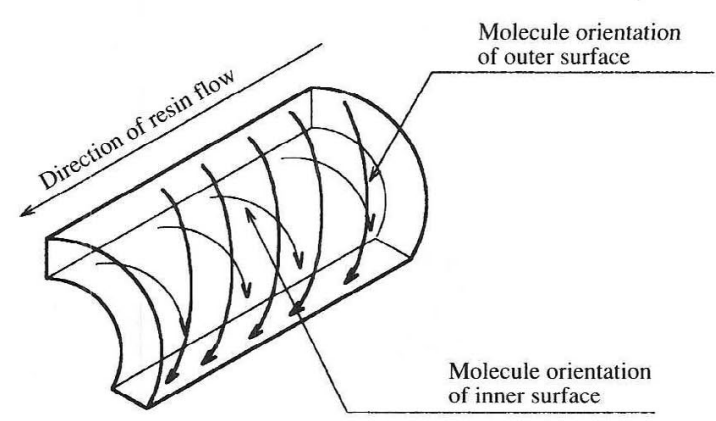

図 10 配向制御された成形品の配向状態図 
りのエネルギー消費に相当すると考える。

図 13 より, 衝撃エネルギー- $\left(G_{I}\right)$ と Trigger 変位 $D_{L}$ は比例関係にあることが明白である。 そして, 単位破壊長 さ当りのエネルギー消費は衝撃エネルギーによって左右さ れることもわかる。また, Trigger 重量と衝撃速度による 影響は小さいと考える.

一般に，エネルギー吸収能力を評㑛する手段として比エ ネルギー忣収量 $E_{S}$ が用いられている。

$E_{s}$ は次式より算出される。

比エネルギー吸収量 $\left(E_{S}\right)=\frac{P}{A \rho}(k J / k g)$

$P$ : 平均荷重 $(\mathrm{N})$

$A$ : 断面積 $\left(\mathrm{cm}^{2}\right)$

$\rho:$ LCP $の$ 密度 $\left(\mathrm{g} / \mathrm{cm}^{3}\right)$

上式より算出した L-tube および S-tube の比エネルギー吸

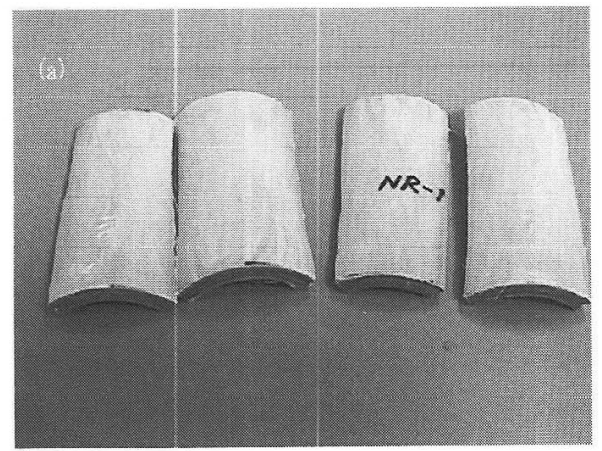

（a）通常成形品

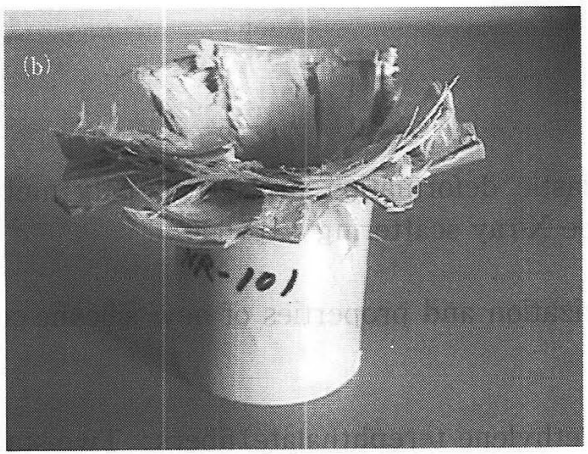

（b）配向制御成形品

図 11 動的圧壞試験における L-tube の試験後の状態
収量 $\left(E_{S}\right)$ を表 1 に示す。

熱硬化性樹脂を使用した樹脂パイプの $E_{S}$ は $9 \mathrm{~kJ} / \mathrm{kg}$ 〜 $180 \mathrm{~kJ} / \mathrm{kg}$ であるのに対し2)，本 LCP パイプ（熱可塑性樹 脂）の $E_{S}$ は $5.3 \mathrm{~kJ} / \mathrm{kg} \sim 14.8 \mathrm{~kJ} / \mathrm{kg}$ と低い值を示した。 熱硬化性樹脂製の樹脂パイプの $E_{S}$ が高いのは，樹脂自体 の姵性と内部に含有されている平織ガラスクロスの強化繊 維のためパイプの剛性が向上しているためと考える。ちな みに, 本 LCP パイプには強化瀻維等の充填材は含有して いない。

また, 自動車が実際に衝突する速度 $(20 \mathrm{~km} / \mathrm{hr} \sim 80 \mathrm{~km} /$ hr）の間にて良好なエネルギー吸収特性を示した。これは， 配向制御技術を用いることで熱可塑性樹脂にて容易にかつ
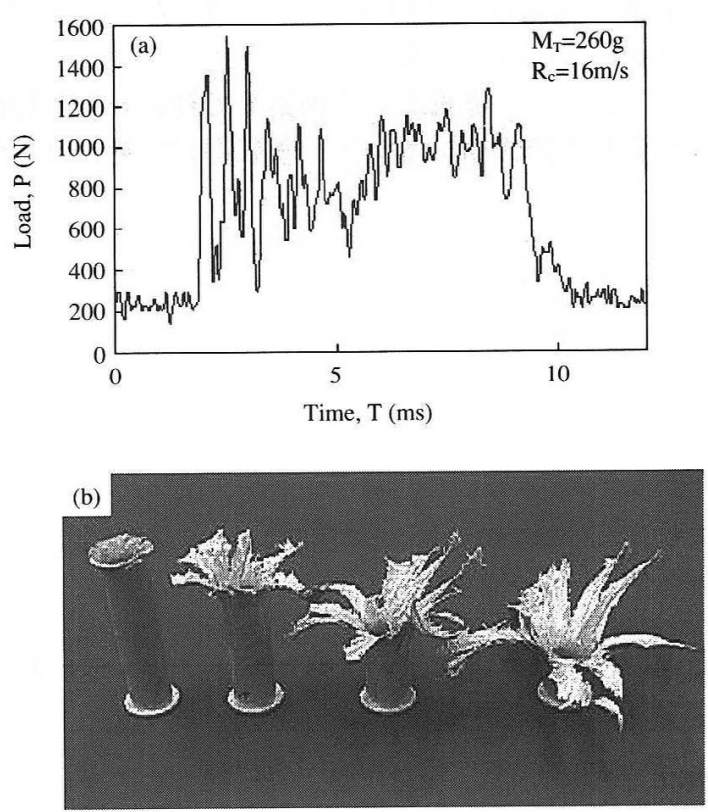

図 12 動的圧壊試験における S-tube 配向制御成形品の エネルギー吸収特性 (a) と試験後の状態 (b)

表 1 比エネルギー吸収量

\begin{tabular}{c|c|c}
\hline 試作品 & $\begin{array}{c}\text { 平均荷重 } \\
(\mathrm{kN})\end{array}$ & $\begin{array}{c}\mathrm{ES} \text { 值 } \\
(\mathrm{kJ} / \mathrm{kg})\end{array}$ \\
\hline L-tube & 2.2 & 5.3 \\
\hline S-tube & 1.1 & 14.8 \\
\hline
\end{tabular}

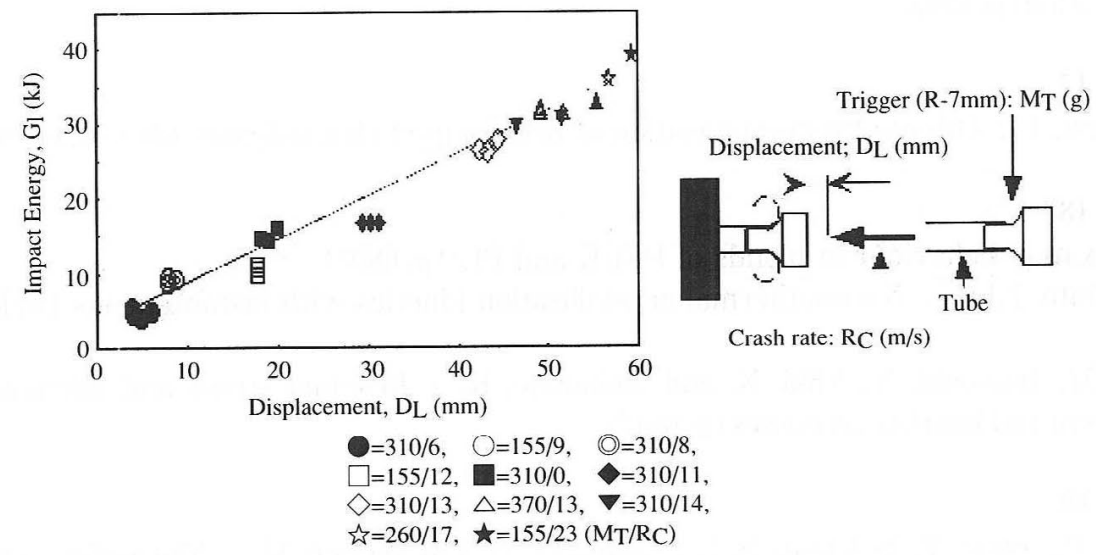

図 13 配向制御された S-tube の動的圧壊試験における衝撃エネルギー $\left(G_{I}\right)$ と Trigger 変位 $\left(D_{L}\right)$ との関係 
安価にエネルギー吸収部材が製造できることを意味する.

なお，総ての動的圧壊試験において，その圧壊様式が “progressive crushing”であることが確認された.

\section{5. ま め}

1）LCP に配向技術を適切に制御させることにより，図 9 や図 12 に示したような信頼のあるエネルギー吸収部 材を射出成形にて生産することが可能である.

2 ）螦旋状に配向された LCP パイプの圧壊挙動やエネル ギー吸収特性には速度依存性がない。

3 ）射出成形に配向制御技術を付加させて製造した螺旋状 配向 LCP パイプは，軸方向にかかる圧縮力に対して 優れたエネルギー吸収特性を示した。

4 ）螦旋状に配向された LCP パイプの圧壊様式は, “progressive crushing”を示した.

これは, ガラス繊維や炭素繊維等で補強した薄層構造 の熱硬化性の樹脂エネルギー吸収部材で見られるもの
と同等である.

5 ) 螺旋状に配向された LCP パイプのエネルギー吸収部 材は熱可塑性樹脂であるためリサイクルが可能であり 環境に優しい部材である。

\section{参 考 文 献}

1) 伴, 岩本：三菱自動車テクニカルレビューNo. 10 (1998)

2 ）濱田, 中谷ら：第 26 回 FRP シンポジウム論文集 II25 A 265 266

3 ）川田, 本多ら：材料，47, No. 5, 458〜463（1998）

4 ）濱田, 斎藤ら：第 28 回 FRP シンポジウム論文集 III -24 B 387 390

5 ) 井上 : 6 th Japan International SAMPE Symposium 697 (1999)

6 ）特許第 2537131 号（株式会社メイホー）

7 ）特許第 3185093 号（株式会社メイホー）

\section{口文献抄録 (3)}

\section{Polymer}

- Vol.41 (2000), No.16

Yamashita, T., and Nabeshima, Y. : Study of the microscopic plastic deformation process in poly (methylmethacrylate)/acrylic impact modifier compounds by means of small angle X-ray scattering (p. 6067)

Wang, W. J., Perng, L. H., Hsiue, G. H. and Chang, F. C. : Characterization and properties of new silicone-containing epoxy $\operatorname{resin}(\mathrm{p} .6113)$

Hobbs, T., and Lesser, A. J. : Preparation of high performance poly (ethylene terephthalate) fibers: Two-stage drawing using high pressure $\mathrm{CO} 2$ (p. 6223)

Li, C. K-Y., Xia, Z-Y. and Sue, H-J. : Simple shear plastic deformation behavior of polycarbonate plate. II. Mechanical property characterization (p. 6285)

- Vol. 41 (2000), No. 17

Yan, S. and Petermann, J. : Oriented recrystallization of pre-oriented thin polymer films (p. 6679)

- Vol. 41 (2000), No. 18

Jenkins, M. J. : Relaxation behaviour in blends of PEEK and PEI(p. 6803)

Martins, J A. Cruz Pinto, J J C. : Non-isothermal crystallisation kinetics with instantaneous nucleation： (p. 6875)

Nishino, T., Kotera, M., Inayoshi, N., Miki, N. and Nakamae, K. : Residual stress and microstructures of aromatic polyimide with different imidization processes (p. 6913)

- Vol.41 (2000), No.19

Charoensirisomboon, P., Inoue, T., Solomko, S. I., Sigalov, G. M. and Weber, M. : Morphology of compatibilized polymer blends in terms of particle size-asphericity map (p. 7033) 